\title{
Temporary appropriation and urban informality: exploring the subtle distinction
}

\section{INTRODUCTION}

Informality has become a major area of interest within the field of urban sciences, and there is a growing body of literature that recognises the potential benefits of informality for the worldwide urban agenda (Pasquetti and Picker, 2017; Georgieva, 2018; Moatasim, 2018; Sarmiento and Tilly, 2018; Kuppinger, 2019). Yet urban informality is difficult to define, and temporary appropriation (TA) is often seen as merely another form of informal urban activity. Among the challenges faced by researchers is first to define urban informality and informal activity within the urban agenda, and second to identify and categorise the different forms of informal activity in cities (Devlin, 2017; Marx and Kelling, 2018). Following on from this, finding out where informal activity and TA intersect and overlap is a challenge in itself.

Looking at urban informality, Holston (2008) states, "...in the process of building their residential spaces, [informal actors] not only construct a vast new city, but on that basis, also constitute it as a polis with a different order of citizen- ship" (2008, p. 311). Some scholars (Caldeira, 1996; Roy and Alsayyad, 2004; Roy, 2012; Lucia Bayer, 2016) have described urban informality as urban practices outside of the legal and economic framework, others (Mayer, 2007; Kinder, 2014) have associated the concept as being part of bottom-up counter strategies against liberal policies, and others as a tool through which urban residents produce the city (Lydon et al., 2012, 2014). Despite the differences between the approaches, all of them indirectly refer to spontaneous and unplanned activities in public spaces as informal practices. Naming a condition allows activist-scholars to shed light on what this condition implies for those living 'in it' and, in the best cases, to empower them (Peattie, 1987) and yet the definitions of the term informality given above connote a binary condition which does not reflect the full gradient of urban life.

TA on the other hand isn't necessarily informal. In its essence it refers to a process whereby public space is 'borrowed' on a time-limited basis. Although generally informal in practice, formalised examples of TA do exist, and include licenced busking such as on the London Underground, licensing for sidewalk vendors as recently introduced in senate bill 946 in California, and pop-up markets, Christmas markets, farmers' markets and other time-limited events in held in public spaces. What is significant here is that the activities which are appropriating public space are temporary in nature, regardless of how formally or informally they were organised.

In this paper we seek to explore the definitions and uses of both TA and informal activity in an urban context. It is not the aim of this paper to discuss the concept of informality within the urban realm, or as a model of expansion of informal settlements, as this has been widely discussed elsewhere (Roy and Alsayyad, 2004;; Holston, 2008; Roy, 2009, 2012; Lutzoni, 2016; Boer et al., 2017; Auerbach et al., 2018; Sarmiento and Tilly, 2018). Likewise we are not pursuing an in depth discussion of the process in which an economic need for TA may be driven by urban informality though this is certainly an important area where these two ideas overlap (International Labour Office, 1972; De Soto, 1989, 2000). We instead maintain our focus on TA itself - often described as the informal behavioural patterns of people occupying public spaces within the formal city. We will explore how urban informality and TA have been conflated, and provide a clear understanding of why they are in fact different. Aligned with recommendations for the new urban agenda by Alfaro d'Alençon, Moretto and Smith (2016) we utilise a new de-centred and de-westernized approach. We will see that TA is more than just a subset of informal urban activity, and that this deeper understanding of TA is significant for advancing our understanding of how public spaces are utilised on a day-to-day basis in different urban contexts.

\section{TEMPORARY APPROPRIATION}

People have an inborn socio-spatial special need to appropriate the built environment (Graumann, 1976; Yory, 2011). According to Lefebvre (1971), the concept of appropriation is one of the most remarkable results that centuries of philosophical reflections have bequeathed. Appropriation is the 
pinnacle of a social life; without appropriation our domination of the natural environment would be absurd. Yory (2011) supports this by arguing that for humanity the construction-appropriation of our environment is something inherent and connatural. The concept of appropriation is implicit in his theoretical definition of topophilia as "the act of co-appropriation generated between the man and the world; through which the world becomes the world, at the opening realised by the man within its historicspatial nature and human becomes human through its spatialisation" (Yory, 2011, p. 45). Whereas humanisation is where the individual internalises a set of fundamental societal defined meanings (Graumann, 1976), appropriation, as an inborn necessity of humans, can be expressed through activities that occur in the urban landscape. Authors such as Purcell (2002), Pol Urrútia (2002) and Yory (2003) have drawn respectively upon Lefebvre, the dual model and topophilia to use appropriation as a term to explain the theoretical link between people and places, and by extension, the contrast between the theoretical and actual use of public spaces.

Public spaces are an essential part of the urban landscape and play host to a range of publicly occurring activities which are of a temporary nature (Noschis et al., 1978; Moudon, 1991; Madanipour, 1996). These activities may vary in the degree to which they are permitted, encouraged, expected and tolerated. Take for instance a mosque on Friday, or a church on Sunday. One would expect people attending Friday prayers or a Sunday service to appropriate these spaces at these times. Activities occurring in these buildings at other times of the week might be less common. Likewise, different groups of people behave differently in these spaces. A group of people at prayer would behave differently to a group of tourists, yet both groups in turn temporarily appropriate the same space. Appropriation is a broad term, and the majority of the literature on the general theme of appropriation refers to it as a lasting and consistent condition (Díaz and Ortiz, 2003; Ramirez-Lovering, 2008; Ardura Urquiaga, 2014). Appropriation which occurs only temporarily, specifically including actions and events which take place within public spaces, and non-permanent, daily or extemporaneous instances of appropriation, has received less critical attention (Fonseca Rodriguez, 2015; Lara-Hernandez, Melis and Caputo, 2017).

In terms of how urban spaces are constructed, the unstoppable growth of cities worldwide is causing us to reflect on their development in terms of sustainability (Lehmann, 2015), and the ways in which urban spaces are used. Recasting the concept of appropriation with respect to urban growth and expansion, TA is a consequence of the necessity of adapting to a cityscape that though sudden and unexpected changes deprives its population of familiar reference points. The temporariness of appropriation becomes an essential element of urban flexibility, on the one hand it grants a citizens rights as a social being living within an urban context, whilst on the other it transforms a public space into a place with the potential to generate an additional sources of income to.

Regarding the urban landscape, some authors (Roy and Alsayyad, 2004; Ramirez-Lovering, 2008; Roy, 2009; Lucia Bayer, 2016) have used TA to refer to the informal or illegal use of urban space. In the context of private land this may be appropriate, however, it is problematic to refer to the use of public space in both an illegal and informal manner, since by convention public space belongs to the citizens. Though this sense of public ownership may be stronger in certain regions or cultures, for instance in the Mediterranean, Latin America or Southeast Asia, although TA is more visible in these areas, this is not to say that it is a purely regional phenomenon.

Fonseca Rodriguez (2015) provides a definition of TA as "the temporary act in which people use public spaces to carry out individual or collective activities other than the purpose that the space was originally designed for," a definition which is incredibly open to a wide range of activities and settings. Thus, TA allows citizens to reshape and redefine urban spaces for their own needs and uses, rather than simply accepting the constraints of the extant build environment. Citizens realise their right to fully exploit and manage their everyday life within the urban environment (Lefebvre, 1992; Purcell, 2002). Graumann (1976) notes that the appropriation of public space is a medium and a goal in order to overcome human alienation, whilst Lara-Hernandez and Melis (2018) argue that TA is the ephemeral and time framed appropriation of the urban environment reflecting an individual, social, and spatial need.

Lara-Hernandez, Melis and Caputo (2017) argue that TA can also be defined as the interaction between citizens and their city expressed through certain kinds of activities occurring in public spaces. Drawing upon the literature they identify three groups of activities that can be considered as expressions of TA. We agree with these authors, but we would like to refine their categories somewhatas follows:

1. Activities related to the economy including work and trade (Crossa, 2009, 2016; Loukaitou-Sideris and Ehrenfeucht, 2009; Kim, 2013; de la Torre, 2015). This includes activities which are mobile in 
nature, such as the small scale, moveable, casual operations included in Bromley (1979) and RamirezLovering (2008)

2. Activities related to leisure (Drummond, 2000; MacDonald and Shildrick, 2007; Hernandez Mendo and Morales Sanchez, 2008; Díaz Larrañaga, Grassi and Mainini, 2011; Simpson, 2011; Mouffe, 2014; Seaman and McLaughlin, 2014).

3. Activities related to religion, culture and heritage (Monnet, 1995; Portal, 2009).

All three contribute towards maintaining the social urban landscape, and examples of the different ways in which these forms of TA can be seen are illustrated in figures 2-4. These forms of TA are not geographically restricted, but have been observed in cities across the world. Although the exact nature of the event may vary from place to place, the three broad categories remain valid for comparing TA in different locations.

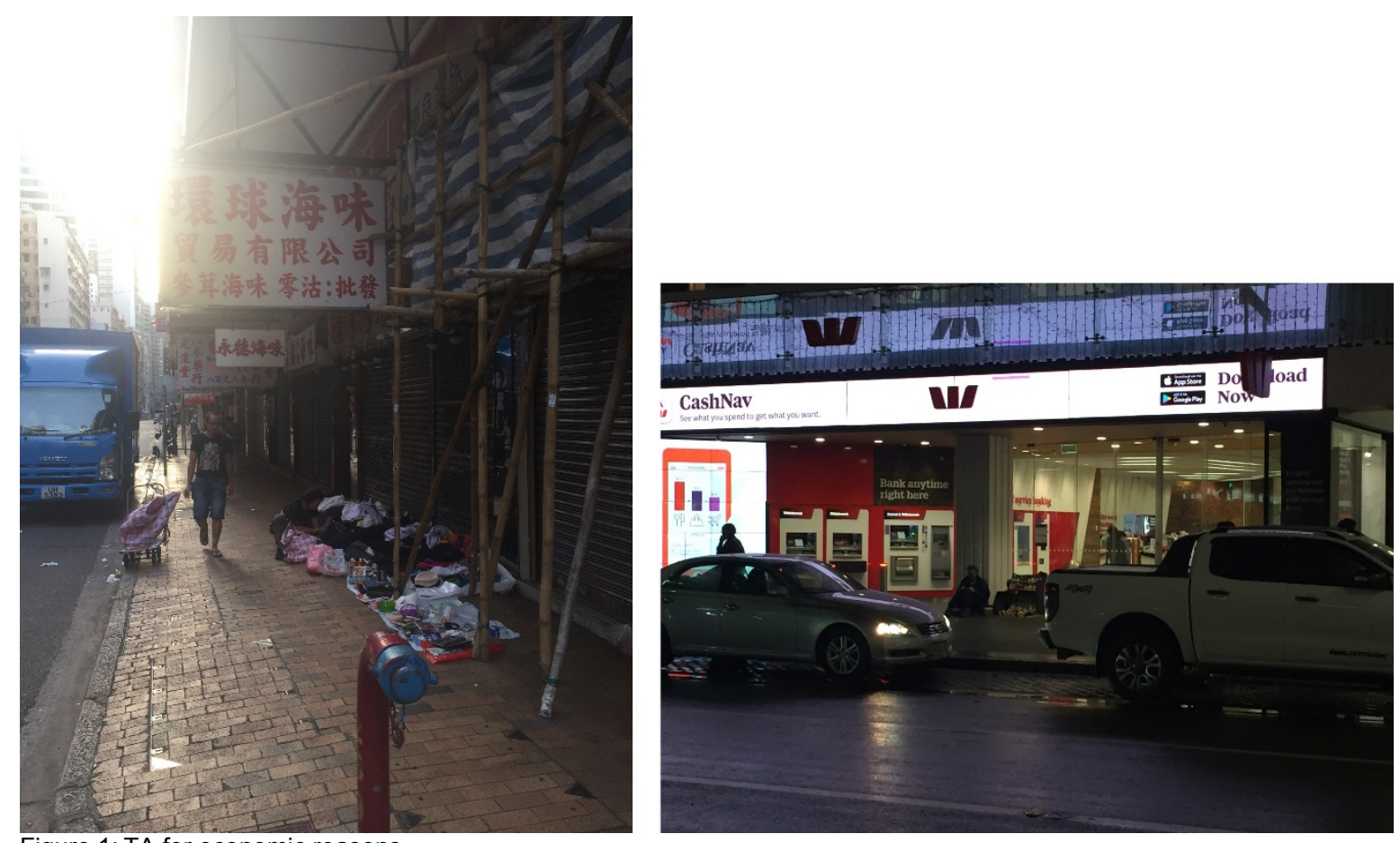

Figure 1: TA for economic reasons

(left) Woman selling clothes in the street in Hong Kong; (right) Man selling handmade souvenirs in Auckland's CBD (Source: Authors). 

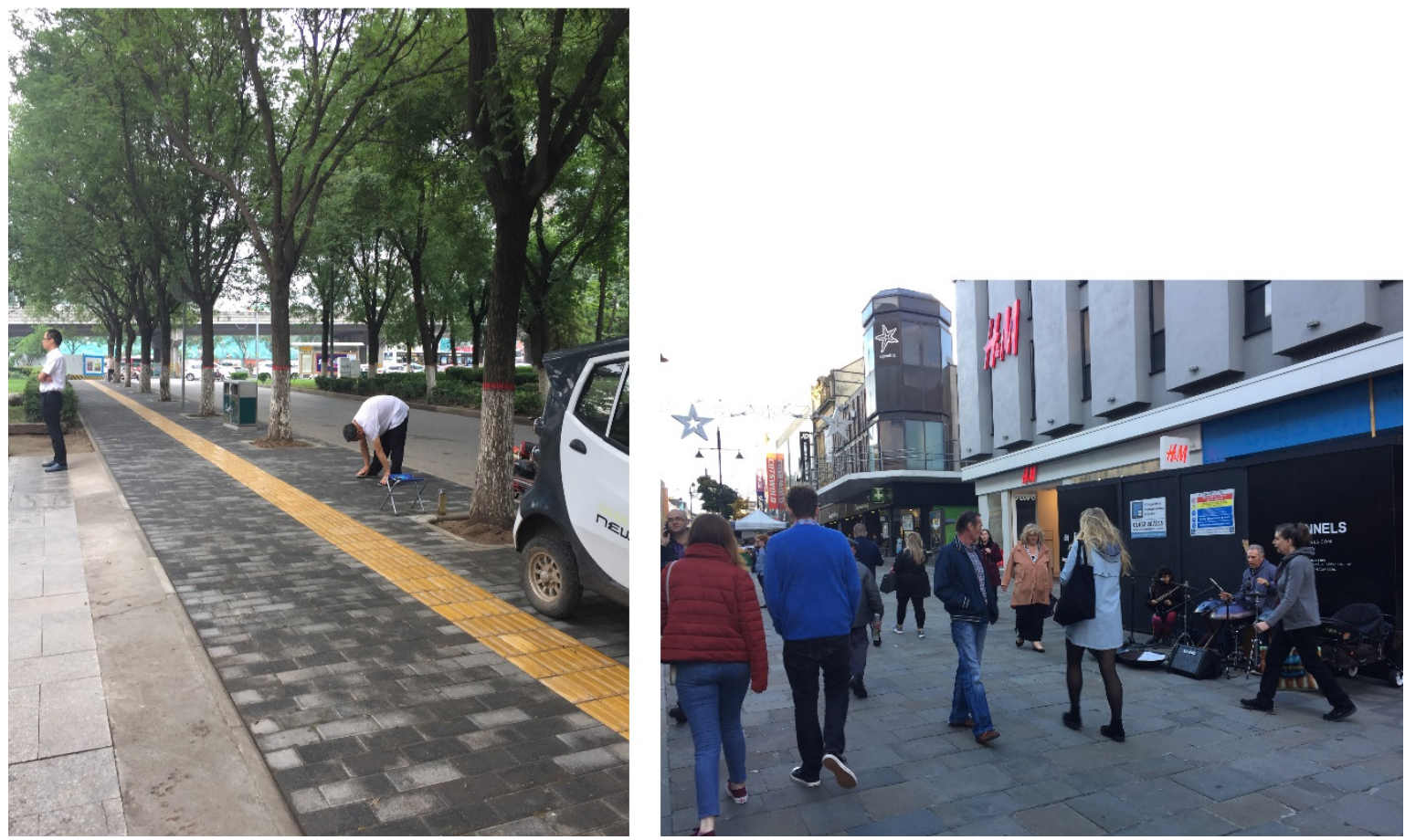

Figure 2: TA for leisure

(left) Man exercising in Xian, China; (right) Band playing music in Newcastle, UK (Source: Authors)
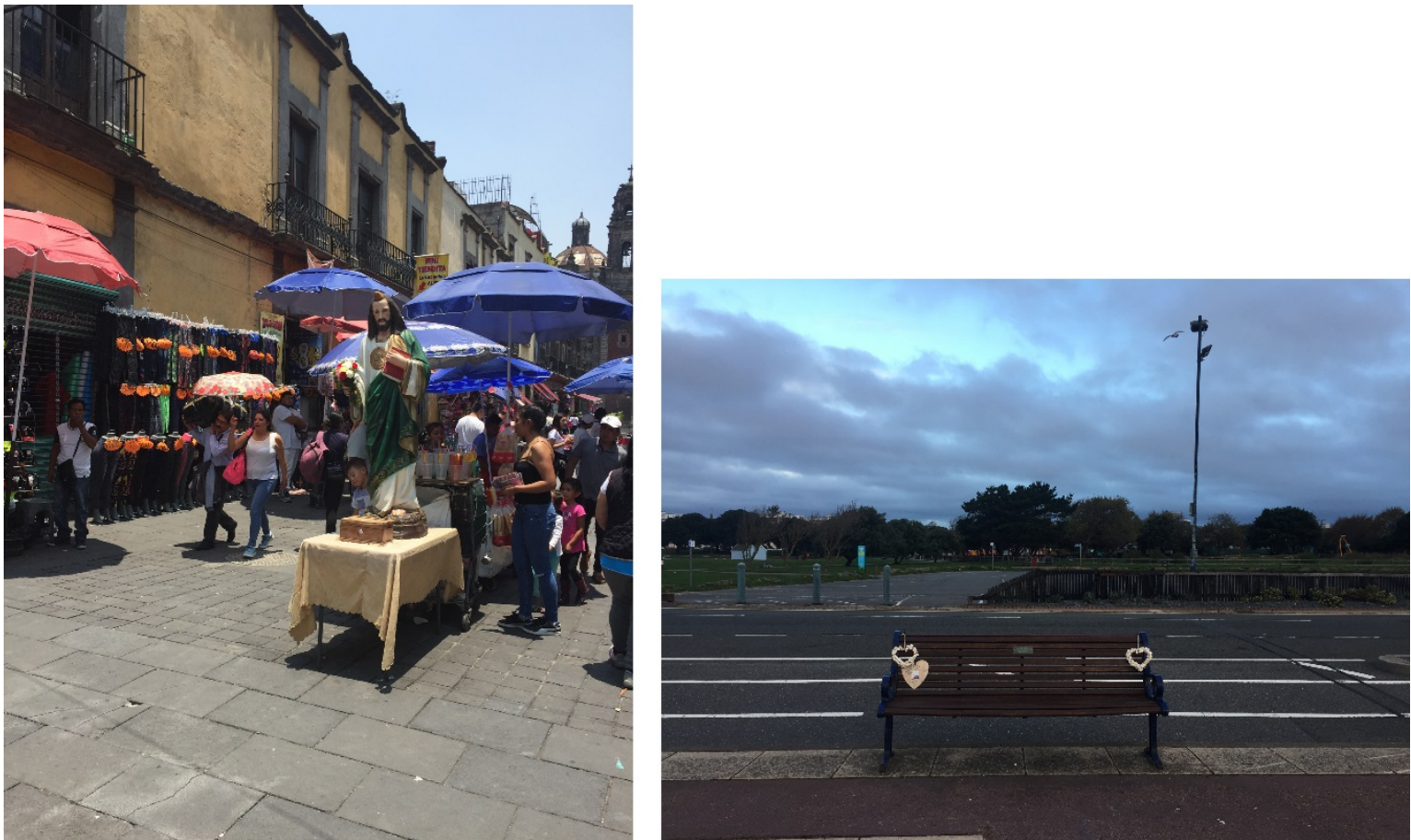

Figure 3: TA in cultural and religious practices

(left) Altar in the street in Mexico City Centre; (right) Remembrance objects on a bench in Portsmouth, UK (Source: Authors)

More recently there has also been increased visibility for political protests expressed as TA. The mass gatherings as part of the Arab Spring, the Occupy and Extinction Rebellion movements, the recent Brexit marches in London, the gilets jaunes demonstrations in France, and the wide scale public protests in Lebanon, Bolivia, Chile, Iraq and Hong Kong are just some examples of mass politically inspired gatherings that have temporarily occupied public spaces. TA can be conceptualised as an assemblage which is in turn a product of other assemblages, particularly local culture, the legal environment, and urban design (Lara-Hernandez, Melis \& Lehmann, 2019) It is multi-scalar, highly complex and has a significant role to play in the construction of the contemporary urban landscape. In the case of Mexico City, Lara-Hernandez, Melis and Lehmann (2019) argue that are not the elements 
themselves (legal framework, cultural mix between Spanish and Aztec, and the design of the built environment) that contribute to the emergence of TA, rather the relationship and the tension between the three components. The constant process of territorialisation and deterritorialisation, both in the individual assemblages and in the wider assemblage product, provide a constantly changing backdrop for a variety of human actions and behaviours. These behaviours, formal or informal, constitute individual moments of appropriation, which together help to form the backbone of the current culture of a given streetscape or public space.

In the discussion above we have shown examples of TA which cover the spectrum of formal and informal behaviour, including both the casual and the organised. Although TA is often seen to intersect with informal urban activity, this is not always the case. In order to clarify the distinction between TA and informal urban activity, in the following two sections we will look at different definitions of informality, and discuss the role of informality and informal activity within urban settlements. This will enable us to have a firmer understanding of what informality could mean in a given streetscape context, and will allow us to begin to explore where TA and informal urban activity overlap, and where they are crucially different.

\section{DEFINING INFORMALITY}

It is difficult to find a common definition of informality; a definition common to different major languages and cultures can be constructed, but loses some of the nuances present in the different original definitions. The Oxford English Dictionary (OED, 2015) defines the informal as 1) not done or made according to a recognized or prescribed form; not observing established procedures or rules; unofficial; irregular and 2) characterized by absence of formality or ceremony; casual, relaxed. Merriam-Webster (2018) similarly refers to the informal as being 1) marked by the absence of formality or ceremony, or 2) characteristic of or appropriate to ordinary, casual, or familiar use. Looking beyond the Anglophone world, it is interesting to compare how informality is defined in other major European languages. The Real Academia Española (2017) defines informal in Spanish as 1) the quality of being non-formal and 2) banned action because of its informal condition. In German, Duden (2018) defines informell as 1) something without a formal assignment and 2) something lacking formality, or which is non official. Treccani (2018) defines the term informale in Italian as something which is non-official, whereas in French, informel will be a new addition to the 9th edition of the Dictionnaire de l'Académie française (2018), showing how this concept has come to prominence since the previous version of the dictionary was published in 1935. In Polish nieformalny is defined as something 1) inconsistent with applicable regulations, and 2) not having an official character (PWN, 2018). Finally in Dutch informeel is defined as 1) non-formal, unofficial and 2) provisional, non-binding (Van Dale, 2018). Despite the similarities between the definitions across the different languages, there is no definitive definition. All of the definitions refer to a lack of formality, many stress unofficial or irregular behaviour, a few imply prohibited actions and only one implies a temporary action. Although the selection of languages given here are purely European in origin, it does show that even within a relatively small geographical area the definition of informality is not consistent or fixed. Thus, it is not surprising to find a similar lack of consistency between definitions of informality in urban research (Holston, 2008; Devlin, 2017; Marx and Kelling, 2018). Urban informality is generally conceived as a dynamic, resilient and adaptable kind of urbanisation occupying voids left by the incapacity and the indifference of the government (Cordera, Ramirez Kuri and Zlccardl, 2008; Devlin, 2017). However, distinctions between types of urban informality are made, and value is attributed differently depending on the context in which informality is perceived to be found. For instance, Devlin (2017) argues that the literature in the "Global North" regarding urban informality is not as rich as the one from the "Global South", claiming that academicians and practitioners have not produced much empirically grounded work on informal spatial practice. Marx and Kelling (2018) support this argument claiming that urban theory embraces informality as a predominantly "something" for understanding "non-western" cities. Aligned with this view Alfaro d'Alençon, Moretto and Smith (2016) highlight the need to look for alternative definitions and terms which recognise the cultural and social legitimacy of so-called urban 'informal' mechanisms, proposing an "alternative formality" emerging from the local context. We would argue that these statements show a narrow understanding of urban informality, seeing it as a process that can only occur within an informal settlement. They fail to recognise TA as a possible form of informal activity which occurs within the formal city and which takes place regardless of the socio-economic setting, a point which will be discussed further later in this paper. 


\section{URBAN INFORMALITY}

Regarding urban studies, the analysis of informality has largely been directed at processes or practices that challenge the established formal system. The term urban informality usually refers to the illegal condition of land occupation for housing purposes by poor and marginalised people (Roy and Alsayyad, 2004; Roy, 2005; Rios, 2014; Lutzoni, 2016). It can also refer to the "informal sector," encompassing a broad set of people and practices defined by economic assessments of their types of employment and main sources of income (Duhau and Giglia, 2007; Cordera, Ramirez Kuri and Zlccardl, 2008; Binelli, 2016; Crossa, 2016). Bayat (1997) argues that poor people have the aspiration to belong, and to practice an integrated life, as long as they can afford the social, cultural and economic cost.

De Soto (1989) defines urban informality as "the key to survival and success ignoring or deliberately breaking unreasonable official rules and regulations in order to make a living and to satisfy basic needs". Due to an inability to access formal financial structures, the disenfranchised rely on sustained informal activity to seek a form of redistribution that ensures survival, better material living conditions, and the autonomy to obtain public goods e.g. possessing land illegally and constructing forms of shelter. The poor in Middle Eastern countries justify their acts of transgression by articulating a moral language or urban politics, which is similar to cases in Latin America (Sen, 1999). In these examples, the key example of urban informal activity is often the construction of settlements and dwellings, followed by engagement in informal employment practices. Some types of informal activity are thus more permanent in nature, whereas others represent an ongoing pattern of temporary behaviour that has less of an impact on the physical infrastructure of a given place, but may have more of an impact on daily life at street level.

We agree with Alfaro d'Alençon, Moretto and Smith (2016) when they claim that the concept of urban informality is far more complex than a binary preconception. They argue that informal activity is strongly linked to other key issues occurring in the urban arena such as negotiation, self-organisation and coproduction. The informal mechanism of urbanisation processes mean that power and dominance are constantly balanced and re-negotiated among urban actors such as the state, private sector and high and/or low-income residents, around resources and legitimacy. It is deemed to be self-organised, because communities have been encouraged by central and local governments to manage all of the processes aligned to the decisions, values and priorities dictated by themselves. Thirdly, an element of co-production is involved, through some degree of service delivery by the state and through public participation, where both of these make substantial resource contributions, empowering local groups. These three aspects are often strictly context specific, thus there is a need for context-based research to understand the dynamics more fully.

Looking beyond the Global South, Devlin (2017) points out that there are two different types of drivers for urban informal practices, first the acts undertaken by the urban poor in order meet basic needs and to survive, and secondly those engaged in by more well-off residents for convenience, efficiency, or creative expression. The former is defined as the "informality of need" while the latter as the "informality of desire". The risk inherent here is that Devlin views both forms of informal practice under the same terms, and makes the tacit assumption that all expressions of informal acts are politically neutral, organic or bottom-up, which in turn has the potential to lend endorsement to neoliberal projects of deregularisation and state retrenchment (Iveson, 2013; Kinder, 2014). Furthermore, there is no distinction made between ongoing patterns of urban informal behaviour, and one-off events that may be more temporary in nature. The perception seems furthermore to be that capital accumulation drives informal activity, whether this is through need or not. Just as with De Soto (2000) the description of urban informality does not encompass leisure activities, religious practices, or other non-capital based activity.

Furthermore, Devlin (2017) categorises studies of informality in three different groups: informality as everyday authenticity, as best practice, and as (Lefebvrian) cry and demand. The first group is represented by advocates such as Jacobs (1961) and De Certeau (1984) who drew attention to a dimension unseen by the planners and designers, who were failing to see and consider the social landscape of the street. The second group corresponds to advocates such as Deleuze and Guattari (1989). Although their theoretical discussions never refer to informality per se, they criticise formal structures of planning and administration (Bogue, 1991). It is characterised by practitioners encouraging citizens to appropriate the urban realm through creative and informal practices. Lydon et al (2014) and their Tactical Urbanism strategies are a good example of this group. Lastly, the third group is divided in two sub-groups: DIY (Do-It-Yourself) Urbanism, and the group of studies referring to community gardens in the USA, Canada and European cities. Both sub-groups are devoted to the notion of the commons and the conflict between use-value and exchange-value of urban space described by 
Lefebvre (Devlin, 2017). These categories of urban informal use range from housing to leisure activities, sharing a Lefebvrian conceptualisation of the politics of spatial production. Devlin argues that direct actions from informal actors aim to fulfil a collective need expressed through social disobedience against property rights. There is a "cry and demand" from urban residents to undertake planning without the state, which is assumed to be a regressive force captured by and serving capitalist interests (Purcell, 2016). Although leisure activities are included in the types of informal activity that are espoused by these groups, not all of informal activity that results from public demand is necessarily temporary in nature, and indeed this activity may have a lasting impact on the immediate cityscape.

Marx and Kelling (2018) categorise informality in the field of urban studies differently. They identified three main approaches in how Anglophone researchers have studied the phenomena in the "western world": informality as a condition, as a law and as a currency. Informality as a condition is the most common way of thinking about urban informality. For instance, UN-Habitat $(2009$; 2013) defines informality on the basis of the nature of property rights, planning, infrastructure and level of services. Marx and Kelling (2018) criticise this view by arguing that it leads to debates about precision and reliability, rather than exploring the reasons about why and how they are applied. Similarly, Soliman (2019) argues that such definition ignores the economic and political dimension of informality, claiming that urban informality is the output of the production, the consumption and the distribution of certain activities and/or commodities in which the capital is the cornerstone of this process. Informality as a law is associated with legal pluralism, which holds that plurality of legal systems co-exist, such as state law, religious law, indigenous law, customary laws and local conventions.

In such a plural realm the law of the state is not necessarily the dominant one. Furthermore, the state might not be able to have the capacity to enforce the law (McAuslan, 2006). Soliman (2019) supports this argument stating that there are differentiations between the written law and the practiced law, the latter is moulded by people, not only the poor but also by the rich, to adapt law according to their interest and to serve their objectives of gaining extra capital out of playing with the law. It follows that what is conventionally taken as formal could be considered as informal and the other way around. Thus, it requires more empirical and detailed analysis to understand the context, especially where it assumes a fluidity and coincides with instances of TA. Lara-Hernandez and Melis (2018) support this argument by arguing that the cultural dimension plays a decisive role in how people make use of spaces. Despite this, it is impossible to escape from the fact that, even though non-governmental regulations may form the dominant structure, there is still some sort of a legal apparatus in operation. Lastly, informality as a currency acknowledges that the informal nature of what is happening in a given situation may not be the most significant feature of this activity. Human practices are socially constructed either through formal or informal routines/norms/rules and these actions have socio-political currency. Informality as currency takes a relational perspective, emphasising flux, changes and dynamic conditions, while still recognising regularity e.g. the ambiguity and even contradictory condition of regulations over the use of public spaces in cities (Lara-Hernandez, Melis and Coulter, 2018).

Following this line of thought, informality is the opposite of formality, but this does not necessarily mean that there is an absence of form or lack of organisational order. This approach acknowledges the local dynamics and relations of the context and specially place towards informality rather those ones coming from neoliberal impulses. These local dynamics and relations occurring in the urban environment are highly relevant for studies focused on informality. Rapoport (2005) states that such studies should take into consideration the interplay between people's activities in their built environment, which is strongly linked to culture. For instance, an easy and extreme example would be a house. He provides an example based on housing by comparing the traditional western setting with a tribal one. Figure 4 illustrates how different activities that take place inside house "A" may occur in a widely dispersed system of settings in the case of house "B". Thus, the units to be studied are not the houses themselves but the system of settings within which particular systems of activities take place. This type of conceptualisation makes a huge difference because it enables us to see the striking disparity between the uses of the two different houses and by extension the use of the street, the neighbourhood and so on. 


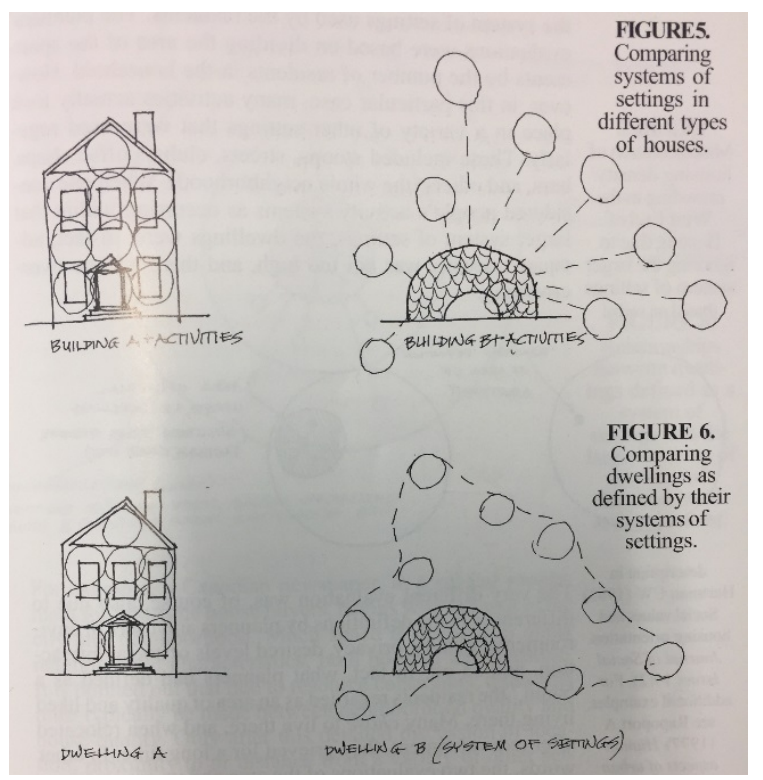

Figure 4: Housing types and activities (source: Rapoport, 2005)

In view of all that has been mentioned above, one may suppose that what could be described as informality in a given context could really be just a different reflection on local dynamics, and relations between people and their built environment. We would like now to explain how TA can be considered as an expression of some of these local dynamics occurring in the urban environment, explaining in more depth the nature of TA as an urban phenomenon and looking at how it differs from some of the types of informal activity that occur in the urban realm.

\section{DISCUSSION: TEMPORARY APPROPRIATION AND URBAN INFORMALITY}

TA is an urban phenomenon that emerges as an expression of local dynamics and relations within a local context, and as something deeply rooted in our human nature. Viewing TA in this light helps to distinguish between the activities related to the appropriation of public space, and the simple use of the space. This position is aligned with what Seghezzo (2009) calls persons, one of five dimensions of sustainability, and differs from the definition favoured by Leary-Owhin (2015), influenced by Lefebvre, that describes TA as a temporally bounded condition imposed upon differential spaces in the urban context. Significantly, when viewing TA as an emerging assemblage, it is possible, but not always necessary, to consider the role of informal activity within this assemblage (Lara-Hernandez, Melis \& Lehmann, 2019). This suggests that TA and informal activity, though linked, are separate concepts.

Previously it was argued that TA is activated by a sense of identity and belonging whose nature is predominantly informal. Likewise, urban informal activities can be seen as a temporary condition which place constraints and restrictions on existing public spaces, structures or norms. As argued at the start of this paper, the use of the term 'informality' by definition implies the assumption of a binary condition, where activities are assigned to either the informal or the formal, and as we have demonstrated in the section above, this is not always appropriate for activities which as part of TA occupy the grey areas in between.

Looking at the areas where urban informality and TA overlap, Bayat (1997) claims that informality is not a crucial predilection of the urban poor, rather it is an alternative choice to the restraints of more formal urban structures. In this respect, we argue that the use of public space is not a binary condition that could be conceptualise into formal or informal, the reality of the urban landscape is far more complex than that. Yet Bayat (1997) rightly criticises the focus on the notion of "civil society" because it tends to ignore the hybrid and un-constitutionalised social activities that dominate urban politics in developing countries. He defines these activities as the quiet encroachment of the ordinary which is "a silent, patient, protracted, and pervasive advancement of ordinary people on the propertied and powerful in order to survive hardships and better their lives". The latter is not what Gramsci (1964) understood as passive revolutionaries, rather it relates back to the concept of an informality of need seen previously (Devlin, 2017). Disenfranchised groups carry out their activities driven by the need to survive, rather than as a conscious political act, and yet their use of public spaces is a not an encroachment since these spaces are by definition for public use. Marx and Kelling (2018) and Devlin (2017) criticise how 
scholars from the Global North have studied informality, and we appreciate the framing of urban informality in this context. However, the main claim of their argument is that urban theory embraces informality as a predominantly something for understanding "non-western" cities, which frames informality very tightly. That for them TA is synonymous with urban informality is more difficult conceptually, since it equates any temporary use of public space with unregulated activity, which we know is not always the case.

A more significant term to conceptualise the relationship between the two concepts is hybridisation, a term provided by the anthropologist Garcia Canclini (2005). He defines hybridization as "the sociocultural processes in which discrete structures or practices, previously existing in separate form, are combined to generate new structures, objects, and practices" (2005, p. XXV). Garcia Canclini therefore distinguishes hybridisation from apparent synonyms such as fusion. Mestizaje ${ }^{1}$, syncretism and fusion are commonly used terms that differ from hybridisation, according to Garcia Canclini's definition. An example of hybridisation (not hybridity) in everyday life could be represented by the actions of the rural migrants who practice economic and symbolic reconversion strategies by adapting their knowledge in order to work and consume in the city. Another example, could be the craftsmen who connect their traditional work with modern uses in order to get the attention of potential urban buyers, or employers who reformulate their culture on the job in the face of new technologies of production; indigenous movements that renovate their demands in transnational politics or in an ecological discourse and learn to communicate these demands via radio, television, and the Internet. Simmel (1969) believed that a marginal personality is a manifestation of cultural hybridisation - of living on a transitional stage between two cultures without being a full member of either. Both previous examples of activities occurring in public spaces are what Lara-Hernandez and Melis (2018) refer as TA in the urban landscape. These activities appearing in a more or less harmonious manner, each of them pursued for its own individual sake, is what produces culture (Eliot, 1949). Lara-Hernandez, Melis and Lehmann (2019) argue that TA is an emerging assemblage product of other assemblages such as the cultural, the legal and the environmental. Deleuze and Parnet (1977) define an assemblage as a "multiplicity which is made up of many heterogeneous terms and which establishes liaisons, relations between them, across ages, sexes and reigns - different natures". Following this argument, we could infer that TA as an emerging assemblage is similar to the process of hybridisation explained earlier.

Urban informality is likewise a construct, with studies on urban informality tending to take one of two main approaches: the technocratic and the organised bottom-up (see Table 1). This system of classification is very simple and allows us to highlight the main characteristics and flaws of each category. The first approach is more common and holds the view of informality following the rules of the legal, economic or planning system. Jacobs (1961) and De Certeau (1984) are the main critics of this approach by highlighting the importance of the social and of informal everyday life in cities. However, it is not clear what sort of city Everyday Urbanism endeavours to produce, only that it should be constructed in a bottom-up, citizen-driven manner (Devlin, 2017). The second approach encompasses tactical urbanism, DIY Urbanism and the group of studies on community gardens in cities in the USA, Canada and Europe. The Lefebvrian inspired scholars do not see freedom and self-determination as ends unto themselves, rather these concepts are conceived as fuel for a specific revolutionary political project-one that reclaims the means of producing the urban from an oppressive nexus of state and capital (Purcell, 2016).

A drawback regarding studies in cities in the Global North is that they lack a level of differentiation between formal and informal activities (Mukhija \& Loutaku-Sideris, 2014; Chase et al., 2008). This lack of differentiation is because northern academics tend to theorise informality using a less holistic approach in comparison to researchers from the Global South, who approach informality as a mode of spatial production possessing a distinctive internal political and spatial logic (Yiftachel and Hedgcock, 1993; Roy and Alsayyad, 2004; McFarlane, 2011). Southern scholarship has clearly pointed out that both the urban elite and urban poor practice informal practices. We agree with Devlin's argument by stating that the study of urban informality in the Global North lacks of theoretical tools to conceptualise the phenomena in a more holistic way. None of the examples mentioned by Devlin occur in an ephemeral and spontaneous way, which would be typical hallmarks of TA, moreover they do not occur in areas that are thought of as public spaces.

\footnotetext{
1 The term is defined as: 1) Interbreeding and cultural intermixing of Spanish and American Indian people (originally in Mexico, and subsequently also in other parts of Latin America); miscegenation, racial and cultural intermixing. 2) The action or process of such racial and cultural intermixing. rare. 3) Latin American people of mixed American Spanish (especially Mexican) and American Indian parentage, considered collectively, rare (Oxford University Press, 2015).
} 
Table 1: Categorisation of urban informality research approaches

\begin{tabular}{|c|c|c|c|}
\hline Informality as: & Main advocates & Characteristics & Flaws \\
\hline $\begin{array}{l}\text { Technocratic } \\
\text { approach }\end{array}$ & $\begin{array}{l}\text { Crawford (2008), } \\
\text { UN-Habitat (2009; } \\
2013) \\
\text { ILO (1972) } \\
\text { McFarlane and } \\
\text { Waibel (2012) }\end{array}$ & $\begin{array}{l}\text { It defines informality on the basis of the } \\
\text { nature of property rights, planning, } \\
\text { infrastructure and level of services. It } \\
\text { emerges from the practices of } \\
\text { categorisation by the state and/or } \\
\text { planning derived by the neoliberalism. It } \\
\text { is associated with legal pluralism which } \\
\text { holds that plurality of legal systems co- } \\
\text { exist, such as state law, religious law, } \\
\text { indigenous law, customary laws and } \\
\text { local conventions. }\end{array}$ & $\begin{array}{l}\text { This approach provides less usefulness } \\
\text { to analyse social processes usually } \\
\text { context-specific that identifies the so } \\
\text { called "urban informality". It evidences } \\
\text { the blind spot of planners and designers } \\
\text { who were trying to tackle urban issues } \\
\text { from a top-down approach by missing } \\
\text { the everyday activities and the organic } \\
\text { social landscape of the streets. It fails to } \\
\text { analyse and describe the informal city } \\
\text { because in the literature, both examples } \\
\text { are usually conceptualise together while } \\
\text { recreation and survival acts belong to a } \\
\text { different human nature. }\end{array}$ \\
\hline $\begin{array}{l}\text { Organised } \\
\text { bottom-up }\end{array}$ & $\begin{array}{l}\text { Florida (2012) } \\
\text { Blomley (2004) } \\
\text { Davis, (1990) } \\
\text { Low (2010) } \\
\text { Low and Smith } \\
\text { (2013) } \\
\text { Mitchell (2006) } \\
\text { Sorkin (1992) } \\
\text { Lydon and Garcia } \\
\text { (2015), (2011) } \\
\text { Hou (2010) }\end{array}$ & $\begin{array}{l}\text { It promotes new and creative ways in } \\
\text { which urban users through informal } \\
\text { tactics can spur and foster urban } \\
\text { innovation by increasing the } \\
\text { competitiveness of cities that } \\
\text { contributes to economic development. } \\
\text { Community gardens are part of a } \\
\text { broader body of work that attributes } \\
\text { political claims to certain kinds of } \\
\text { informal use of abandoned or marginal } \\
\text { spaces in the industrial city. Such } \\
\text { informal uses vary from fulfilling basic } \\
\text { needs like housing to a more leisurely } \\
\text { activities like artistic activities and all of } \\
\text { them share a Lefebvrian } \\
\text { conceptualisation of the politics of } \\
\text { spatial production. }\end{array}$ & $\begin{array}{l}\text { The focus on process (theoretically } \\
\text { rigorous though it may be), combined } \\
\text { with a notion of desirable outcomes that } \\
\text { is only roughly sketched, leaves the } \\
\text { door open for practitioners to put these } \\
\text { ideas to work in a way that lacks any } \\
\text { sort of radical edge or concern for the } \\
\text { well-being of disadvantaged } \\
\text { communities. }\end{array}$ \\
\hline
\end{tabular}

The conceptualisation of TA enables us to understand the system of activities within the urban dynamics of a local context in a more holistic manner. "A system of activities occur within a specific system of settings, what does or does not happen in some settings influences what happen or does not happen in other" (Rapoport, 2005, p. 23). The latter is closely linked to rules about what behaviour is permitted and what is forbidden in different settings. The rules are part of culture because they dictate who does what, where, when, and why, including or excluding whom. We agree with Rapoport (2005) when he emphasises that a system of settings is part of a larger system of settings (street, block, borough and so on).

\section{CONCLUSION}

The objective of this paper is to open the discussion on the relationship between two complementary concepts, TA and urban informal activity. Although distinct, there is certainly a large amount of overlap between the two. Some urban informal activity is temporary and appropriates public space, and some instances of TA are the product of informal behaviour. To some extent there is a lack of consensus about the definition of informality, and how it varies across languages and urban regions. Language forges thoughts and culture, and therefore influences how we understand and experience our environments (Henle, 1965; Ahearn, 2012). Despite this, there has been a wider understanding of urban informality within the academic arena; when reviewing the literature, it has sometimes been difficult at a glance to separate the more permanent instances of informality from those that are intentionally temporary. There has also been a lack of consistency with regard to the term urban informality, and to its study within both an appropriate and a transferable context.

It has been argued that TA emerges from the local context as a product of the relations and dynamics in the urban environment, which are culturally driven. In addition, the manuscript has provided a categorisation of TA by providing examples from different cities and cultures. By separating TA from urban informality, we have been able to create a simpler model for understanding urban informality, whilst at the same time crystallising TA as a concept in its own right.

A review of the study of approaches focused on informality in the Global North has been provided, categorising them in two main groups. What is surprising is that even though studies usually refer to informal activities occurring in public spaces as evidence of "informal behaviour" none of them provide substantial evidence. It can thus be suggested that TA is usually overlooked and misinterpreted as informal urban practices, while there could be activities, practices or/relations emerging in any local 
context. This also supports our earlier observations, which showed that a holistic approach is needed to study urban informality. The study of urban informality is cross-disciplinary, multidimensional and strongly correlated with other aspects of the city and society. Moreover, the complexity of the multidimensional concept allows for the development of case-specific and place-specific research, which suggests that each study focussed on urban informality should be specific for its particular context. Several authors (Garcia Canclini, 2005; Bayat, 1997; Holston, 2009; Devlin, 2017; Marx \& Kelling, 2018) have suggested that the study of urban informality will benefit from multidisciplinary approaches such as the one presented here. However, further studies need to be carried out in this field of research. We agree with researchers such as Kates et al. (2001) and Clark and Dickson (2003) that there is a need to further push the importance of studies about human transformation as being essential to the scientific empirical agenda for the common interest.

Our findings have significant implications for the understanding of informal processes and activities in cities. This work contributes to existing knowledge on urban informality by providing the TA as a medium through which to study the urban landscape at the level of public spaces. Within the field of architecture (landscape, urban design and planning), more information on the design features of the built environment related to TA in any determinate context would help us to establish a greater degree of accuracy in this matter. Some of the questions raised by this study are where does informality intrude, or prevent TA? How does TA happen without informality being present? There is a definite need for a deeper understanding of TA and its relationship with the urban informality of any socio-cultural landscape.

It is worth mentioning that in western societies public spaces are typically only occupied temporarily during special events, e.g. Trafalgar Square in London or Times Square in New York as forms of temporary appropriation. These spaces revert back to their usual use following public events. In developing countries, public spaces initially appropriated temporarily for leisure purposes may in fact change over time into informal permanently occupied spaces. For example, public housing complexes become green areas, and then into informal built-up areas (see Tipple, 2000). In the US on the other hand, large shopping malls and private parks constitute pseudo public space, feeling like public spaces when in fact they are privately owned. The forms of TA exercised within a public space may over time be able to change a public space to a private space and vice versa, but this merits further investigation than this paper will allow.Informality encompasses far more than just urban dynamics, complex and cannot be fully discussed here, TA helps to understand how people use the street and public spaces on an informal basis, but also increasingly occurs in a more formal and pre-planned way. Cultural differences shape the ways in which TA emerges, and where it lies on the informal spectrum, but whatever the situation people still find a way to exercise some form of right to the city 


\section{REFERENCES}

Académie Française (2018) Académie Française. Available at: http://www.academie-francaise.fr/ledictionnaire/la-9e-edition (Accessed: 26 November 2018).

Ahearn, L. M. (2012) Living Language: An introduction to linguistic anthropology. Oxford, UK: Blackwell Publishers Ltd.

Alfaro d'Alençon, P., Moretto, L. and Smith, H. (2016) N-AERUS Recommendations for the New Urban Agenda. Quito, Ecuador: Cities Alliance. Available at: http://n-aerus.net/wp/wpcontent/uploads/2017/02/N-aerus_Recommendations-for-the-New-Urban-Agenda_DIGITAL.pdf.

Ardura Urquiaga, Á. (2014) 'Madrid. Espacio público confiscado. La privatización y resignificación del espacio público en los procesos de transformación material de las plazas del centro de Madrid', Scripta Nova. Revista Electrónica de Geografia y Ciencas Sociales. Available at: http://www.ub.edu/geocrit/coloquio2014/Alvaro Ardura Urquiaga.pdf.

Auerbach, A. M. et al. (2018) 'State, Society, and Informality in Cities of the Global South', Studies in Comparative International Development, pp. 1-20. doi: http://dx.doi.org/10.1007/s12116-018-9269-y.

Bayat, A. (1997) 'Un-civil society: The politics of the "informal people"', Third World Quarterly, 18(1), pp. 53-72. doi: 10.1080/01436599715055.

Binelli, C. (2016) 'Wage inequality and informality: evidence from Mexico', IZA Journal of Labor and Development. IZA Journal of Labor \& Development, 5(1), pp. 1-18. doi: 10.1186/s40175-016-0050-1.

Blomley, N. (2004) Unsettling the city: Urban land and the politics of property, Development. London, UK: Routledge London.

Boer, R. et al. (2017) 'The end of informality', Volume 52.

Bogue, R. (1991) Deleuze and Guattari. New York: Selwood Printing Ltd. West Sussex. doi: $10.2307 / 3684887$.

Burton, E. and Mitchell, L. (2006) Inclusive urban design: Streets for life, Chemistry \& .... Oxford, UK: Architectural Press. Available at: http://onlinelibrary.wiley.com/doi/10.1002/cbdv.200490137/abstract\%5Cnhttp://issuu.com/filipesilva/do cs/ililbykhz2.

Caldeira, T. P. R. (1996) 'Building up walls: The new pattern of spatial segregation in Sao Paulo', International Social Science Journal, 48, pp. 55-.

Certeau, M. de (1984) The Practice of Every Day Life, Practice. Edited by S. Rendall. Los Angeles, USA: University of California Press.

Chase, J. L. and Crawford, M. (2008) 'Everyday urbanism',. Edited by J. Kaliskl.

Clark, W. C. and Dickson, N. M. N. (2003) 'Sustainability science: the emerging research program', Proceedings of the National Academy of Sciences of the United States of America, 100(14), pp. 805961. doi: 10.1073/pnas.1231333100.

Cordera, R., Ramirez Kuri, P. and Zlccardl, A. (2008) Pobreza, desigualdad y exclusion social en la ciudad del siglo XXI. Mexico, DF: Universidad Nacional Autonoma de Mexico.

Crossa, V. (2009) 'Resisting the Entrepreneurial City: Street Vendors' Struggle in Mexico City's Historic Center', International Journal of Urban and Regional Research, 33(1), pp. 43-63. doi: 10.1111/j.14682427.2008.00823.x.

Crossa, V. (2016) 'Searching for order on the "dirty" streets of the city. Displacement of street vendors in colonial and postcolonial Mexico City', in Contested Cities. Madrid, España.

Van Dale (2018) Gratis woordenboek. Available at: https://www.vandale.nl/gratiswoordenboek/nederlands/betekenis/informeel\#.W_v-L_n7SUI (Accessed: 26 November 2018).

Davis, M. (1990) City of quartz: Excavating the future in Los Angeles. London, UK: Verso.

Deleuze, G. and Guattari, F. (1989) A Thousand Plateaus: Capitalism and Schizophrenia, Journal of Interdisciplinary History. Edited by B. Massumi. Minneapolis, USA: University of Minnesota Press. doi: $10.2307 / 203963$. 
Devlin, R. T. (2017) 'Asking "Third World questions" of First World informality: Using Southern theory to parse needs from desires in an analysis of informal urbanism of the global North', Planning Theory, pp. 1-20. doi: 10.1177/1473095217737347.

Díaz, F. and Ortiz, A. (2003) 'Ciudad e Inmigración: Uso y Apropiación del Espacio Público en Barcelona', pp. 399-407. Available at: http://www.insumisos.com/lecturasinsumisas/Apropiacion del espacio publico.pdf.

Díaz Larrañaga, N., Grassi, L. and Mainini, C. (2011) 'Socialidad: Los modos de apropiación del espacio público', Question, 1(29), p. $12 . \quad$ Available http://perio.unlp.edu.ar/ojs/index.php/question/article/view/572/849.

Drummond, L. B. W. (2000) 'Street Scenes: Practices of Public and Private Space in Urban Vietnam', Urban Studies, 37(12), pp. 2377-2391. doi: 10.1080/00420980020002850.

Duden (2018) Duden | in-for-mell | Rechtschreibung, Bedeutung, Definition, Synonyme, Herkunft. Available at: https://www.duden.de/rechtschreibung/informell_unfoermlich_formlos (Accessed: 26 November 2018).

Duhau, E. and Giglia, A. (2007) 'Nuevas centralidades y practicas de consumo en la Ciudad de Mexico: Del microcomercio al hipermercado', Eure, 33(98), pp. 77-95. doi: 10.4067/S025071612007000100005.

Eizenberg, E. (2011) 'Actually Existing Commons: Three Moments of Space of Community Gardens in New York City', Antipode, 44(3), pp. 764-782. doi: 10.1111/j.1467-8330.2011.00892.x.

Florida, R. (2012) 'The Rise of the Creative Class', The Washington Monthley, May, pp. 15-25. Available at: https://www.os3.nl/_media/2011-2012/richard_florida__the_rise_of_the_creative_class.pdf.

Fonseca Rodriguez, J. M. (2015) 'La importancia y la apropiación de los espacios públicos en las ciudades', Revista de Tecnologia y Sociedad, 4(7), pp. 1-11.

Garcia Canclini, N. (2005) Hybrid cultures. Minneapolis, USA: University of Minnesota Press.

Georgieva, K. (2018) The biggest challenge for the future of work hasn' $t$ changed for decades, World Economic Forum. Available at: https://www.weforum.org/agenda/2018/07/technology-can-help-springworkers-from-the-informality-

trap/?utm_source=sfmc\&utm_medium=email\&utm_campaign=2653547_Agenda_weekly-27July2018staff\&utm_term=\&emailType=Newsletter (Accessed: 28 July 2018).

Gerry, C. (1979) 'Small scale manufacturing and repairs in Dakar : a survey of market relations in the urban economy', in Bromley, R. and Gerry, C. (eds) Casual Work and Poverty in Third World Cities. New York, USA: John Wiley \& Sons, Inc.

Gramsci, A. (1964) Note sul Machiavelli, sulla politica e sullo stato moderno. G. Einaudi.

Graumann, C. F. (1976) 'The concept of appropriation (aneignung) and modes of appropriation of space'. Universitat Heidelberg, pp. 301-313. Available at: http://iaps.scix.net/cgibin/works/Show?iaps_00_1976_009.

Henle, P. (ed.) (1965) Language, Thought, \& Culture. University of Michigan Press.

Hernandez Mendo, A. and Morales Sanchez, V. (2008) 'Una revisión teórica: ocio , tiempo libre y animación sociocultural', Efdeportes.com, pp. 9-12. Available at: http://www.efdeportes.com/efd127/una-revision-teorica-ocio-tiempo-libre-y-animacionsociocultural.htm.

Holston, J. (2008) Insurgent citizenship: Disjunctions of democracy and modernity in Brazil. New Jersey, USA: Princeton University Press.

Hou, J. (2010) Insurgent public space: guerrilla urbanism and the remaking of contemporary cities. New York, USA: Routledge.

International Labour Office (1972) Employment, Incomes and Equality. Geneva, Switzerland.

Iveson, K. (2013) 'Cities within the City: Do-It-Yourself Urbanism and the Right to the City', International Journal of Urban and Regional Research, 37(3), pp. 941-956. doi: 10.1111/1468-2427.12053.

Jacobs, J. (1961) The Death and Life of Great American Cities, New York. doi: 10.2307/794509. 
Kates, R. W. et al. (2001) 'Sustainability Science', Science's Compass, 292(April), pp. 641-642.

Kim, A. M. (2013) Sidewalk City. Chicago, US: The University of Chicago Press. doi: 10.7208/chicago/9780226119366.001.0001.

Kinder, K. (2014) 'Guerrilla-style Defensive Architecture in Detroit: A Self-provisioned Security Strategy in a Neoliberal Space of Disinvestment', International Journal of Urban and Regional Research, 38(5), pp. 1767-1784. doi: 10.1111/1468-2427.12158.

Kuppinger, P. (2019) 'Informal Place-Making: Mosques, Muslims, and Urban Innovation in Germany', in The Palgrave Handbook of Bottom-Up Urbanism. Palgrave Macmillan, Cham, pp. 149-162.

de la Torre, M. I. (2015) 'Espacio público y colectivo social', Nova Scientia, 14(7), pp. 495-510.

Lara-Hernandez, J. A. and Melis, A. (2018) 'Understanding the temporary appropriation in relationship to social sustainability', Sustainable Cities and Society. Elsevier Ltd., 39C, pp. 1-14. doi: 10.1016/j.scs.2018.03.004.

Lara-Hernandez, J. A., Melis, A. and Caputo, S. (2017) 'Understanding Spatial Configuration and Temporary Appropriation of the Street in Latin American cities: the case of Mexico City Centre', in Boudagh, $\mathrm{H}$. et al. (eds) Urban Planning and Architectural Design for Sustainable Development. Palermo, Italy: IEREK, Springer, pp. 153-173.

Lara-Hernandez, J. A., Melis, A. and Coulter, C. M. (2018) 'Using the street in Mexico City Centre: temporary appropriation of public space vs legislation governing street use', Journal of Public Space. City Space Architecture / UN-Habitat, 3(3), pp. 25-48. doi: 10.32891/jps.v3i3.1135.

Lara-Hernandez, J. A., Melis, A. and Lehmann, S. (2019) 'Temporary appropriation of public space as an emergence assemblage for the future urban landscape: The case of Mexico City', Future Cities and Environment. Ubiquity Press, 5(1), pp. 1-22. doi: 10.5334/fce.53.

Leary-Owhin, M. (2015) 'A Fresh Look at Lefebvre's Spatial Triad and Differential Space: A Central Place in Planning Theory?', in 2nd Planning Theory Conference University of the West of England, pp. 1-8.

Lefebvre, H. (1971) De lo rural a lo urbano, Ediciones Península. Edited by J. Gonzalez-Pueyo. Barcelona, España: Ediciones Peninsula.

Lefebvre, H. (1992) The Production of the Space. 1996th edn. Cambridge, Massachusetts: Blackwell Publishers Ltd.

Lehmann, S. (2015) 'Low Carbon Cities: More than just Buildings', in Lehmann, S. (ed.) Low Carbon Cities: Transforming Urban Systems, pp. 1-56.

Loukaitou-Sideris, A. and Ehrenfeucht, R. R. (2009) Sidewalks Conflict and Negotiation over Public Space, Urban Policy and Research. USA: Massachusetts Institute of Technology.

Low, S. M. (2010) On the plaza: The politics of public space and culture. Texas, USA: University of Texas Press.

Low, S. and Smith, N. (2013) The politics of public space. New York, USA: Routledge.

Lucia Bayer, M. F. (2016) 'Conlictos en torno al espacio urbano y dinámicas de apropiación en el Río de Janeiro Olímpico. El caso de Villa Autódromo', Congreso Internacional Contested.

Lutzoni, L. (2016) 'In-formalised urban space design. Rethinking the relationship between formal and informal', City, Territory and Architecture. Springer Berlin Heidelberg, 3(1), p. 20. doi: 10.1186/s40410016-0046-9.

Lydon, M. et al. (2012) Tactical Urbanism: Short Term Action | Long Term Change. beta. New York, US: Street Plans Collaborative.

Lydon, M. et al. (2014) Tactical Urbanism. New York, US: Street Plans.

Lydon, M. and Garcia, A. (2015) 'A tactical urbanism how-to', in Tactical urbanism. Springer, pp. 171208.

MacDonald, R. and Shildrick, T. (2007) 'Street Corner Society: Leisure Careers, Youth (Sub)culture and Social Exclusion', Leisure Studies, 26(3), pp. 339-355. doi: 10.1080/02614360600834826.

Madanipour, A. (1996) Design of urban space. An inquiry into socio-spatial process. New York, US: 
John Wiley \& Sons, Inc.

Marx, C. and Kelling, E. (2018) 'Knowing urban informalities', Urban Studies, 1(16). doi: $10.1177 / 0042098018770848$.

Mayer, M. (2007) 'Contesting the neoliberalization of urban governance', Contesting neoliberalism: Urban frontiers. Guilford Press New York, NY, pp. 90-115.

McAuslan, P. (2006) 'Legal Pluralism as a Policy Option: Is it Desirable, Is it Doable?', Land Rights for African Development From Knowledge to Action, 2005, pp. 9-10. Available at: http://www.capri.cgiar.org/wp/..\%5Cpdf\%5Cbrief_land-04.pdf.

McFarlane, C. (2011) 'The city as assemblage: Dwelling and urban space', Environment and Planning D: Society and Space, 29(4), pp. 649-671. doi: 10.1068/d4710.

McFarlane, C. and Waibel, M. (2012) Urban informalities: reflections on the formal and informal. London, UK: Ashgate Publishing, Ltd.

Merriam-Webster (2018) Dictionary by Merriam-Webster. Available at: https://www.merriamwebster.com/ (Accessed: 26 November 2018).

Moatasim, F. (2018) 'Entitled urbanism: Elite informality and the reimagining of a planned modern city', Urban Studies, pp. 1-17. doi: 10.1177/0042098018767011.

Monnet, J. (1995) Usos e imágenes del centro histórico de la Ciudad de México. Edited by Centro de estudios mexicanos y centroamericanos.

Moudon, A. V. (1991) Public Streets for Public Use. New York, US: Columbia University Press.

Mouffe, C. (2014) Agonística. Pensar el mundo políticamente. Edited by S. Laclau. Mexico, DF: Fondo de Cultura Económica de Argentina.

Noschis, K. et al. (1978) 'Appropriation of space: a method and two case studies', Ekistics, 45(273), pp. 451-466.

Oxford University Press (2015) Oxford English Dictionary Online, Oxford English Dictionary. Available at: http://dictionary.oed.com (Accessed: 12 May 2015).

Pasquetti, S. and Picker, G. (2017) 'Urban informality and confinement: Toward a relational framework', International Sociology, 32(4), pp. 532-544. doi: 10.1177/0268580917701605.

Peattie, L. (1987) 'An idea in good currency and how it grew: The informal sector', World Development, 15(7), pp. 851-860. doi: 10.1016/0305-750X(87)90038-6.

Pol Urrútia, E. (2002) ‘El modelo dual de la apropiación del espacio en Mira, R., Sabucedo, JM y Romay, J.', Psicología y Medio Ambiente. Aspectos psicosociales, educativos y metodológicos, pp. 123-132.

Portal, M. A. (2009) 'Las creencias en el asfalto . La sacralización como una forma de apropiación del espacio público en la ciudad de México', Cuadernos de Antropología Social, (30), pp. 59-75.

Purcell, M. (2002) 'Excavating Lefebvre: The right to the city and its urban politics of the inhabitant', GeoJournal, 58, pp. 99-108. doi: 10.1023/B:GEJO.0000010829.62237.8f.

Purcell, M. (2016) 'For democracy: Planning and publics without the state', Planning Theory, 15(4), pp. 386-401. doi: 10.1177/1473095215620827.

PWN (2018) Słownik Języka Polskiego. Available at: https://sjp.pwn.pl/szukaj/nieformalny.html (Accessed: 26 November 2018).

Ramirez-Lovering, D. (2008) Opportunistic urbanism. Melbourne, Australia: RMIT Press.

Rapoport, A. (2005) Culture, Architecture, and Design. Chicago: Locke Science Publisher.

Real Academia Española (2017) informal | Definición de informal. Available at: http://dle.rae.es/?id=LXum6xU (Accessed: 25 October 2018).

Rios, M. (2014) 'Implications for Urban Design', in Mukhija, V. and Loukaitou-Sideris, A. (eds) The Informal American City. Mit Press, pp. 173-191.

Roy, A. (2005) 'Urban informality: Toward an epistemology of planning', Journal of the American Planning Association, 71(2), pp. 147-158. doi: 10.1080/01944360508976689. 
Roy, A. (2009) 'Strangely familiar: Planning and the worlds of insurgence and informality', Planning Theory, 8(1), pp. 7-11. doi: 10.1177/1473095208099294.

Roy, A. (2012) 'Urban Informality: The production of space and practice planning', The Oxford Handbook of Urban Planning, (July 2018), pp. 1-17. doi: 10.1093/oxfordhb/9780195374995.013.0033.

Roy, A. and Alsayyad, N. (2004) Urban informality: Transnational perspectives from Midle East, Latin America and South Asia. Oxford, UK: Lexington Books.

Sarmiento, H. and Tilly, C. (2018) 'Governance Lessons from Urban Informality', Politics and Governance, 6(1), p. 199. doi: 10.17645/pag.v6i1.1169.

Seaman, J. and McLaughlin, S. (2014) 'The importance of outdoor activity and place attachment to adolescent development in Coös County, New Hampshire', Building knowledge for families and communities. Carsey Institute. Available at: http://scholars.unh.edu/carsey/208/.

Seghezzo, L. (2009) 'The five dimensions of sustainability', Environmental Politics, 18(4), pp. 539-556. doi: 10.1080/09644010903063669.

Sen, A. (1999) Development Freedom, Development Freedom. New York, USA: Oxford University Press.

Simpson, P. (2011) 'Street performance and the City: Public space, sociality, and intervening in the everyday', Space and Culture, 14(4), pp. 415-430. doi: 10.1177/1206331211412270.

Soliman, A. M. (2019) 'So It's Always a Chance: Community-Led Solutions to New Urban Expansion', in Attia, S., Shafik, Z., and Ibrahim, A. (eds) New Cities and Community Extensions in Egypt and the Middle East: Visions and Challenges. Springer, pp. 159-179.

De Soto, H. (1989) The Other Path: The Invisible Revolution in the Third World. Tauris.

De Soto, H. (2000) The mystery of capital: Why capitalism triumphs in the West and fails everywhere else. Basic Civitas Books.

Tipple, A. G. (2000) Extending themselves: User-initiated transformations of government-built housing in developing countries. Liverpool, UK: Liverpool University Press.

TRECCANI (2018) informale in Vocabolario - Treccani. Available at: http://www.treccani.it/vocabolario/informale/ (Accessed: 25 October 2018).

Un-Habitat (2013) Planning and Design for Sustainable Urban Mobility: Global Report on Human Settlements 2013. doi: http://www.indiaenvironmentportal.org.in/content/382038/planning-and-designfor-sustainable-urban-mobility-global-report-on-human-settlements-2013-policy-direction.

UN-Habitat (2009) Planning Sustainable Cities - Global Report on Human Settlements 2009, Earthscan. doi: 10.1007/s13398-014-0173-7.2.

Yiftachel, O. and Hedgcock, D. (1993) 'Urban social sustainability: the planning of an Australian city', Cities. Elsevier, 10(2), pp. 139-157.

Yory García, C. M. (2003) Topofilia, ciudad, territorio: una estrategia pedagógica de desarrollo urbano participtivo con dimensión sustentable para las grandes metrópolis de América Latina en el contexto de la globalización: 'el caso de la ciudad de Bogotá'. Universidad Complutense de Madrid. Available at: http://biblioteca.ucm.es/tesis/ghi/ucm-t26725.pdf.

Yory, M. C. (2011) 'El Concepto de Topofilia entendido como Teoría del Lugar', Revista Barrio Taller, pp. 1-17. 
Antonio Lara-Hernandez: Conceptualization, Methodology, Data curation, Original draft preparation, Reviewing and Editing

Claire Coulter.: Methodology, Original draft preparation, Reviewing and Editing, Project administration

Alessandro Melis: Conceptualization, Supervision, Reviewing and Editing 